\title{
Comparison of Airborne Laser Scanning (3D) with Sentinel-2 (2D) for Estimating Above Ground Biomass/Carbon Stock in a Subtropical Chir Pine Forest of Balakot, Pakistan
}

Sami Ullah ( $\nabla$ samidawar@gmail.com )

Shaheed Benazir Bhutto University https://orcid.org/0000-0002-6997-137X

Tahir Saeed

National University of Science and Technology

Muhammad Shafique

University of Peshawar

Muhammad Saad

University of Haripur

Adnan Khan

Shaheed Benazir Bhutto University Sheringal

\section{Research}

Keywords: ALS, multispectral, Biomass, carbon stock, Chir Pine forest

Posted Date: February 9th, 2021

DOI: https://doi.org/10.21203/rs.3.rs-173795/v1

License: (c) (i) This work is licensed under a Creative Commons Attribution 4.0 International License.

Read Full License 


\section{Abstract}

Forest ecosystems act as a sink of atmospheric carbon dioxide in the form of biomass, and plays one of the crucial role for carbon sequestration and in regulating the global carbon cycle. Few studies based on ground sample plots were conducted for estimating forest biomass/carbon stock across Pakistan. This study comparing the first time the potential of three dimensional (3D) airborne laser scanning (ALS) with two dimensional (2D) Sentinel-2 to estimate above-ground biomass/carbon stock (AGB/C) in a Subtropical Chir Pine forest of Balakot, Pakistan. We derived height and density metrics from the ALS canopy height model (CHM), and different metrics from Sentinel-2 images, and were regressed with field measured $A G B / C$ at sample plots locations. We found $R^{2}=0.86$ with $R M S E \%=25.70$, and $R^{2}=0.62$ with RMSE\% $=43.92$ for ALS and for Sentinel-2 respectively with ground measured AGB/C at sample plots locations. Our study demonstrated that 3D ALS technology has greater potential and is the most accurate option as compared to 2D Sentinel-2 for regular planning and monitoring of AGB/C in the context of the national forest inventory of Pakistan. Our study will be useful for the accomplishment of the REDD+ in measuring, reporting, and verification of forest resources, and future sustainable utilization of forest, safeguarding the livelihoods of forest-dependent people, and reducing pressure on forest ecosystems.

\section{Introduction}

Regular and updated information about vegetation biomass assessment is crucial for quantifying carbon stocks of different forest types, their storing potential, and energy source for future protection, conservation, and reporting. Many countries have committed themselves to regular reporting of carbon stock under the background of climate change initiatives such as the Kyoto protocol which is based on biomass inventories (Fassnacht et al. 2021; Patenaude et al. 2005). Hence, a developing country like Pakistan also needs to make a strategy for regularly assessing their vegetation biomass potential at a national level or at least in smaller spatial units. Very few studies have been reported based on ground sample plots for estimating forest biomass/carbon stock across Pakistan (Ahmad et al. 2018a; Ahmad et al. 2018b; Ahmad et al. 2014; Ahmad and Nizami 2015; Amir et al. ; Mannan et al. 2019; Uddin et al. 2019). However, in the case of ground sample inventories, the accuracy can be limited to the sample plots, and cannot cover spatial variation of large geographical forest area. Combining remote sensing datasets with a field-based sample forest inventory can be a promising outcome for the wall-to-wall mapping of large geographical forest areas (Ullah et al. 2017a; Ullah et al. 2019).

Among remote sensing datasets, airborne laser scanning (ALS) technology has revolutionized forest mapping, and are using constantly for operational forest management in many Nordic countries (Maltamo and Packalen 2014; Næsset 2007; Næsset 2014; Ullah et al. 2017a). Over the last decade, many worthiest studies have been reported by estimating vegetation biomass in different forest regions across the globe using ALS technology. (Domingo et al. 2018; Ene et al. 2018; Ene et al. 2016; Gobakken et al. 2012; Hansen et al. 2015; Maltamo et al. 2016). Unfortunately, not a single study was reported yet in Pakistan by assessing the potential usage of ALS technology for estimating forest biomass and other structural parameters. Thanks to the 477 Pakistan Army Survey Group for introducing this wonderful 
technology which is now available in Pakistan for different applications and has greater potential in forest science. Also, none of the ALS based studies specifically focused on characterizing vegetation biomass of subtropical Chir pine forest. To our knowledge, this will be the first study in Pakistan by testing the capability of ALS for the assessment of above-ground vegetation biomass/carbon (AGB/C) stock in the subtropical Chir Pine forest of Balakot, Pakistan.

Besides the availability of 3D technology such as ALS for research, and smaller spatial units to forest communities in Pakistan, the open-source 2D spaceborne sensors has also greater potential for regular planning and monitoring of natural resources. Although, some remote sensing studies have already been reported by using the space-borne multispectral 2D data in Pakistan (Butt et al. 2015; Iqbal and Khan 2014; Qamer et al. 2016; Qasim et al. 2011; Raziq et al. 2016; Saleemi 2015; Shehzad et al. 2014; Ullah et al. 2016; Ullah et al. 2017c), but all of them related to spatial-temporal forest cover and others land-use change assessment. Hence, we are also evaluating the open-source 2D Sentinel-2 sensor for the assessment and mapping of $\mathrm{AGB} / \mathrm{C}$ to explore viable options to forest administration for regular and updated information about the forest resources of Pakistan.

More specifically, our research aim is to compare the potential of ALS (3D) technology with Sentinel-2 (2D) for estimating above AGB/C stock in a Subtropical Chir Pine Forest of Balakot, Pakistan. The output of this study will be used as baseline information to the forest administration of Pakistan to think about the possible introduction of remote sensing technology for regular planning and monitoring of their natural resources.

\section{Materials And Methods}

\section{Study area, and field inventory}

The study was conducted at Balakot, district Mansehra of Khyber Pakhtunkhwa province of Pakistan. It is extending from latitude $34^{\circ} 33^{\prime} 21.32^{\prime \prime} \mathrm{N}$, and longitude $73^{\circ} 19^{\prime} 58.03^{\prime \prime} \mathrm{E}$ to latitude $34^{\circ} 32^{\prime} 58.34^{\prime \prime} \mathrm{N}$ and longitude $73^{\circ} 20^{\prime} 41.50 " \mathrm{E}$ on the right side of River Kunhar. Its elevation ranges from 1031 meters to 1472 $\mathrm{m}$ above sea level. The rainfall takes place mostly from February-March (late winter) and June-August (the monsoon season). The forest type of the study site dominated by Pinus roxburghii (Chir pine) with a few associated species that include Poplus nigra (Poplar), Ailanthus altissima (tree of heaven), Salix tetrasperma (willow tree), Ficus caricia (Fig), and Broussonetia papyrifera (Paper mulberry). Figure 1 depicts the geographical location of the study site.

Field data were collected from 24 August 2019 to 05 September 2019 where tree measurements were done from randomly selected 30 sample plots each having $17.84 \mathrm{~m}$ of radii. The center coordinates of sample plots were recorded with Stonex X5 GPS which has sub-metric accuracy. In every selected plot area, all trees having a width of greater than $7 \mathrm{~cm}$ were selected and their diameter at breast height point (DBH) and heights was measured. Finally, above-ground biomass per KG was derived for each tree using the following allometric equation developed by Ali et al. (2020). 
Chir Pine biomass $(K G)=0.0224 \times\left(D^{\wedge} 2 \times(H)^{\wedge} 0.9767\right) \quad E q-1$

Where $\mathrm{H}$ represents the height of the tree, and $\mathrm{D}$ stands for Diameter at the level of breast height point. The single measured tree biomass per sample plots was summed up and finally converted into tons/hectare by using the expansion factor. The carbon stock is usually regarded as about half of the dry biomass. Hence, the total biomass per sample plots/KG was converted by multiplying the 0.50 value (Walker et al. 2011). Table 1 depicts the summary of the measured biomass, and carbon stock of the ground inventory sample plots.

Table 1. Summary of the AGB/C (T/ha) of ground inventory sample plots

\begin{tabular}{|lllll|}
\hline summary & Minimum & Mean & Std & Max \\
AGB (T/ha) & 0 & 11.3 & 10.43 & 26.27 \\
AGC (T/ha) & 0 & 5.65 & 5.22 & 13.14 \\
\hline
\end{tabular}

\section{Remote sensing data and its processing}

The details of the ALS data used in our study are shown in Table 1.

Table 3. Details of airborne laser scanning (ALS) used in the study

\begin{tabular}{|ll|}
\hline Parameters & ALS \\
\hline Flying height & 3300 meter above sea level \\
\hline Field of view (full scan angle) & 30 \\
\hline Strip distance (m) & $900 \mathrm{~m}$ \\
\hline Measurement rate / scan rate & Commanded $38.3 \mathrm{~Hz}$ _Max58.4 Hz \\
\hline Point density & 1.1 per meter square \\
\hline Acquisition Data & $30^{\text {th }}$ August $2017(10: 45$ to 13:30) \\
\hline Flying velocity & 175 kts \\
\hline
\end{tabular}

The 3D ALS point clouds were used to generate the Digital Surface Model (DSM) and Digital Terrain Model (DTM) with $1 \mathrm{~m}$ spatial resolution. The DSM generation was accomplished through the selection of the maximum option which uses the highest points within the $1 \mathrm{~m}$ spatial resolution pixel as a filtering and natural neighbor as an interpolation. Similarly, for the DTM generation, the minimum option was selected in which the lowest point is used within a resolution of $1 \mathrm{~m}$ pixel as a filtering and natural neighbor as an interpolation. Finally, the Canopy Height Model (CHM) of $1 \mathrm{~m}$ was generated by subtracting the corresponding DTM from DSM. 


\section{Extraction of metrics from ALS CHM}

The most commonly used derived metrics from ALS CHM in forest inventory are the height, and its percentiles (Næsset 2004). A total of 15 height metrics extracted from the ALS CHMs using a $12 \mathrm{~m}$ radius circle corresponds to the size of ground sample plots. For instance, the metrics extracted were the

minimum $\left(h_{\text {min }}\right)$, mean $\left(h_{\text {mean }}\right),\left(h_{\text {max }}\right)$, range $\left(h_{\text {range }}\right)$, and the height percentiles i.e., hp99, hp95, hp90, $\mathrm{hp} 80 \ldots$... hp10. We also calculated the coefficient of variation $\left(\mathrm{h}_{C V}\right)$, standard deviation $\left(\mathrm{h}_{\text {STD }}\right)$, and range from the $\mathrm{CHMs}$ by taking into consideration the variation and heterogeneity of ALS CHM. The metrics, as mentioned above, derived from the vertical distribution of CHMs. We also calculated the canopy cover density (cd), and canopy volume $\left(\mathrm{h}_{\text {sum }}\right)$, for the horizontal distribution of the canopy structure. The cd is calculated by dividing the number of pixels with heights above $2 \mathrm{~m}$ by the total number of pixels within an area of $12 \mathrm{~m}$ radius circular sample plots. Besides, 10 types of other forest cover density metrics such as $\mathrm{cd} 1, \mathrm{~cd} 2$, and $\mathrm{cd} 3 \ldots \mathrm{cd} 10$ were extracted at sample plots location. More detail of the abovementioned metrics can be found in our previously published papers (Ullah et al. 2017a; Ullah et al. 2017b; Ullah et al. 2020; Ullah et al. 2019).

\section{Extraction of metrics from Sentinel-2}

For estimating above ground biomass/carbon stock etc., different vegetation indices plus the spectral bands of the multispectral Sentinel-2 images were used. The most commonly used extracted vegetation indices in our study were the normalized difference vegetation index (NDVI) (Rousel et al. 1973), difference vegetation index (DVI) (Tucker 1979), Green difference vegetation index (GDVI) (Sripada 2005), Enhanced Vegetation Index (EVI) (Huete et al. 2002), Green Leaf Index (GLI) (Louhaichi et al. 2001), Nonlinear Vegetation Index (NLI) (Goel and Qin 1994), SR (Jordan 1969), Green Normalized Difference Vegetation Index (GNDVI) (Gitelson and Merzlyak 1998), RDVI (Roujean and Breon 1995), weighted difference vegetation index (WDVI), soil adjusted vegetation index (SAVI) (Huete 1988), Global Environment Monitoring Index (GIMI) (Pinty and Verstraete 1992), and Green Optimized Soil Adjusted Vegetation Index (GOSAVI) (Sripada 2005), etc.

\section{Modeling for predicting carbon stock}

Before fitting multiple regression models, the multicollinearity problem was resolved between the extracted explanatory variables of the ALS CHM and Sentinel-2. The problem of multicollinearity between the explanatory variables ( $>0.7$ correlation) was eliminated by using the variance inflation factors. The variation inflation factor for each of the variables was calculated and the variables were sequentially dropped, which were found to be above a pre-specified threshold value (>2) according to a suggestion made by Zuur et al. (2010). We used the CAR package of the R-statistics for calculating the variance inflation factor (Fox and Weisberg 2018). After solving the problem of multicollinearity between the explanatory variables, a multiple linear regression model was fitted between the height variables/metrics 
obtained from the ALSCHMs, and Sentinel-2 as explanatory variables, and the biomass/carbon stock (tons/ha) as the response variables. Subsequently, a stepwise method was applied to remove the explanatory variables by minimizing the Akaike information criterion. For reporting RMSE and RMSE\%, leave-one-out cross-validation was used in which each observation was regarded as a testing set whereas the remaining data were used as a training set. The caret package in $R$-statistics software was used to analyze and compute all the calculations (Kuhn 2008). After the selection of the final most model, the final metrics selected were generated on a rasterized cell size corresponds to the ground sample plots using a wall-to-wall mapping approach. Figure 2 depicts the flow chart of the research methodology adopted in our study.

\section{Results}

The final most explanatory variable selected for the prediction of biomass/carbon stock using ALS CHM were the $\mathrm{h}_{\text {range }} \mathrm{h}_{\text {mean }}$, and $\mathrm{h}_{\text {STD }}$ (Table 4). Similarly, the final most explanatory variable selected for the prediction of biomass/carbon stock using Sentinel-2 were the NDVI, and NLI (Table 4). We found R ${ }^{2}$ $=0.86$, and $\mathrm{R}^{2}=0.62$ for the ALS CHM, and Sentinel-2 respectively with the ground measured biomass/carbon stock. More detail can be found in Table 4 .

Table 4. Final most explanatory variables and results for estimating forest $A G B / C$ (T/ha) 


\begin{tabular}{|c|c|c|c|c|}
\hline ALS & Selected variables & Coefficients & $\mathbf{R}^{2}$ & Adjusted $\mathrm{R}^{2}$ \\
\hline \multirow[t]{4}{*}{ ALS AGB t/ha-1 } & intercept & 0.06 & 0.86 & 0.85 \\
\hline & $\mathrm{h}_{\text {range }}$ & -0.59 & & \\
\hline & $\mathrm{h}_{\text {mean }}$ & -1.95 & & \\
\hline & $\mathrm{h}_{\text {std }}$ & $6.30 * \star$ & & \\
\hline \multirow[t]{4}{*}{ ALS AGC t/ha-1 } & intercept & 0.03 & 0.86 & 0.85 \\
\hline & $\mathrm{h}_{\text {range }}$ & -0.29 & & \\
\hline & $\mathrm{h}_{\text {mean }}$ & -0.97 & & \\
\hline & $\mathrm{h}_{s t d}$ & $3.15^{\star \star}$ & & \\
\hline \multirow[t]{3}{*}{ Sentinel-2 AGB t/ha ${ }^{-1}$} & intercept & $4.986^{*}$ & 0.62 & 0.59 \\
\hline & NDVI & $54.49 * \star \star$ & & \\
\hline & $\mathrm{NLI}$ & $-0.000005^{\star \star}$ & & \\
\hline \multirow[t]{3}{*}{ Sentinel-2 AGC t/ha ${ }^{-1}$} & intercept & $2.49 *$ & & \\
\hline & NDVI & $27.25^{\star \star \star}$ & & \\
\hline & NLI & $-0.0000023^{\star \star}$ & & \\
\hline
\end{tabular}

Note: $R^{2}=$ coefficients of determination and ( ${ }^{\star \star \star} p<0.001$, ${ }^{\star *} p<0.01$, ${ }^{\star} p<0.05$, and $\left.p<0.1\right)$ indicates the level of significance of the t-test

Our results showed that ALS based CHM showed higher accuracy with RMSE\% $=25.70$ as compared to Sentinel-2 with RMSE\% = 43.92 (Table 5).

Table 5. Comparison of RMSE, RMSE\%, and MAE between predicted versus observed above ground biomass/carbon stock (T/ha- $\left.{ }^{-1}\right)$ 


\begin{tabular}{|llll|}
\hline RS data & RMSE (m3 ha-1) & RMSE \% & MAE \\
\hline ALS & & & \\
\hline AGB t/ha-1 & 2.98 & 25.70 & 2.98 \\
\hline AGC t/ha-1 & 1.49 & 25.70 & 1.49 \\
\hline Sentinel-2 & & & \\
\hline AGB t/ha-1 & 5.10 & 43.92 & 5.54 \\
\hline AGC t/ha ${ }^{-1}$ & 2.55 & 43.92 & 2.77 \\
\hline
\end{tabular}

Figure 3 showed scatter plots between the observed versus predicted biomass/carbon stock (tons $/ \mathrm{ha}^{-1}$ ) for both ALS and Sentinel-2.

The final predicted AGB/C maps for both ALS CHM, and Sentinel-2 are shown in Figure 4.

The summary statistics of predicted maps between the predicted and observed AGB/C are shown in Figure 5. Our results also showed here that ALS CHM is more closed to field based observation as compared to Sentinel-2 in terms of comparison of mean AGB/C (ton/ha).

\section{Discussion}

3D ALS has revolutionized forest mapping, and many developed countries adopted this technology for operational forest management. However, the potential usage of this technology is never explored for different forestry applications in developing countries like Pakistan. That's the reason that forest administration in Pakistan is unaware of the potential usage of ALS data for different forestry applications. We assess the potential usage of a 3D ALS active airborne sensor for the first time in Pakistan to estimate AGB/C in a Subtropical Chir Pine Forest of Balakot, Pakistan. For ALS based CHM, we obtain $\mathrm{R}^{2}=0.85$ with $\mathrm{RMSE} \%=25.70$ again ground $\mathrm{AGB} / \mathrm{C}$ (ton/ha). Our obtained biomass prediction results are in agreement with other comparable earlier studies in the context of estimating forest AGB/C across the different forested regions (Baccini and Asner 2013; Bright et al. 2012; García et al. 2010; Næsset 2011; Stephens et al. 2007). It can be noted that we didn't find any previous study about Pakistan, and Subtropical Chir Pine forest for estimating forest AGB/C (T/ha).

Besides the availability of the ALS data for only research and smaller spatial scales in Pakistan, we also tested the 2D open-source multispectral Sentinel-2 data to explore the other possible viable option to the forest community for regular reporting and monitoring of the forest resources. For 2D Sentinel-2 multispectral data, we obtained $\mathrm{R}^{2}=0.62$ with $\mathrm{RMSE}=43.92$ for estimating $\mathrm{AGB} / \mathrm{C}$ in a Subtropical Chir Pine Forest of Dir Kohistan. Our obtained results in term of RMSE \% values of Sentinel-2 imagery for estimating AGB/C seems to be slightly lower but can be par as compared to previous results obtained by 
Nuthammachot et al. (2020), Nuthammachot et al. (2018), Pandit et al. (2018), and Vafaei et al. (2018) which can due to different forest types, altitudinal gradients, etc.

Summarizing the findings of our results 3D ALS sensor showed high accuracy and thus has greater potential as compared to 2D multispectral Sentinel-2 imagery for estimating AGB/C in a Subtropical Chir Pine forest of Balakot, Pakistan. Further, the prediction models derived from both ALS CHM and Sentinel2 images fulfill the normality assumption since they are highly significant and their probability is greater than 0.05 . The out of the results can be successfully employed for the regular assessment and mapping of $A G B / C$ of the Subtropical Chir Pine forest at both the local and regional scale studies.

\section{Conclusions/outlook}

Despite well-proven tested ALS technology in developed countries, the forest community in Pakistan is unaware of its potential usage in the field of forest science. The present study attempt to motivate the forest communities towards the potential usage and possible introduction of remote sensing technology such as 3D ALS data for different application in the field forest sciences across Pakistan. We demonstrated successfully the usage and potential of 3D ALS sensors for estimation forest AGB/C of Subtropical Chir Pine forest for the first time in the history of Pakistan. However, it can be tested in the future as well for the other essential forest types of Pakistan. Besides the availability of the costly option such as ALS data, or which can only be affordable for research and smaller spatial scales in Pakistan, we also tested the 2D open-source multispectral Sentinel-2 data to open other viable ways to forest community for regular reporting and monitoring of the forest resources. The finding of the results shares useful information and methodology regarding the uses of 3D ALS technology, and 2D multispectral Sentinel-2 images in combination with field data for provincial, national forest department, environments, climatologist, and REDD + policymakers in Pakistan.

\section{Declarations}

\section{Author contribution}

Dr. Sami Ullah is the lead author and was involved in the overall project designing, remote sensing and field data collection, analysis, and writing etc. Mr. Tahir Sayed arrange the ALS data, and it's preprocessing. Dr. Muhammad Shafique help in writing up the manuscript. Mr. Muhammad Saad help in allometric equation and processing of field data. Mr. Adnan help in field data collection, Sentinel-2 images preprocessing steps, and writing.

\section{Acknowledgement}

We are thankful to 477 Pakistan Army Survey Group for the arrangement and provision of ALS data. We are also thankful to the ESA Copernicus mission for free access of downloading Senitnel-2 imagery through Earth Explorer i.e. https://earthexplorer.usgs.gov. Finally, we are thankful to the GIS \& Space Applications in Geosciences (G-SAG) laboratory at the NCE in Geology, University of Peshawar, with the 
partnership of Shaheed Benzair Bhutto University, Center of GIS and Space Applications for providing remote sensing processing facilities, financing field data collection, and expertise etc.

\section{References}

Ahmad A et al. (2018a) The Carbon Sinks and Mitigation Potential of Deodar (Cedrus deodara) Forest Ecosystem at Different Altitude in Kumrat Valley, Pakistan. Open Journal of Forestry 8:553-566

Ahmad A, Liu Q-J, Nizami S, Mannan A, Saeed S (2018b) Carbon emission from deforestation, forest degradation and wood harvest in the temperate region of Hindukush Himalaya, Pakistan between 1994 and 2016. Land use policy 78:781-790

Ahmad A, Mirza SN, Nizami S (2014) Assessment of biomass and carbon stocks in coniferous forest of Dir Kohistan, KPK. Pakistan Journal of Agricultural Sciences 51

Ahmad A, Nizami SM (2015) Carbon stocks of different land uses in the Kumrat valley, Hindu Kush Region of Pakistan. Journal of forestry research 26:57-64

Ali A, Ashraf Ml, Gulzar S, Akmal M (2020) Development of an allometric model for biomass estimation of Pinus roxburghii, growing in subtropical pine forests of Khyber Pakhtunkhwa. Pakistan Sarhad Journal of Agriculture 36:236-244

Amir M et al. Soil carbon storage potential in deodar (Cedrus deodara) Forest of Kumrat Valley, Pakistan

Baccini A, Asner GP (2013) Improving pantropical forest carbon maps with airborne LiDAR sampling. Carbon Management 4:591-600

Bright BC, Hicke JA, Hudak AT (2012) Estimating aboveground carbon stocks of a forest affected by mountain pine beetle in Idaho using lidar and multispectral imagery. Remote Sensing of Environment 124:270-281

Butt A, Shabbir R, Ahmad SS, Aziz N (2015) Land use change mapping and analysis using Remote Sensing and GIS: A case study of Simly watershed, Islamabad, Pakistan. The Egyptian journal of remote sensing and space science 18:251-259

Domingo D, Lamelas MT, Montealegre AL, García-Martín A, De la Riva J (2018) Estimation of total biomass in Aleppo pine forest stands applying parametric and nonparametric methods to low-density airborne laser scanning data. Forests 9:158

Ene LT et al. (2018) Large-area hybrid estimation of aboveground biomass in interior Alaska using airborne laser scanning data. Remote Sensing of Environment 204:741-755

Ene LT et al. (2016) Large-scale estimation of aboveground biomass in miombo woodlands using airborne laser scanning and national forest inventory data. Remote Sensing of Environment 186:626-636 
Fassnacht FE, Poblete-Olivares J, Rivero L, Lopatin J, Ceballos-Comisso A, Galleguillos M (2021) Using Sentinel-2 and canopy height models to derive a landscape-level biomass map covering multiple vegetation types. International Journal of Applied Earth Observation and Geoinformation 94:102236

Fox J, Weisberg S (2018) An R companion to applied regression. Sage publications,

García M, Riaño D, Chuvieco E, Danson FM (2010) Estimating biomass carbon stocks for a Mediterranean forest in central Spain using LiDAR height and intensity data. Remote Sensing of Environment 114:816830

Gitelson AA, Merzlyak MN (1998) Remote sensing of chlorophyll concentration in higher plant leaves. Advances in Space Research 22:689-692

Gobakken T et al. (2012) Estimating biomass in Hedmark County, Norway using national forest inventory field plots and airborne laser scanning. Remote Sensing of Environment 123:443-456

Goel NS, Qin W (1994) Influences of canopy architecture on relationships between various vegetation indices and LAI and FPAR: A computer simulation. Remote Sensing Reviews 10:309-347

Hansen EH, Gobakken T, Bollandsås OM, Zahabu E, Næsset E (2015) Modeling aboveground biomass in dense tropical submontane rainforest using airborne laser scanner data. Remote Sensing 7:788-807

Huete A (1988) Huete, AR A soil-adjusted vegetation index (SAVI). Remote Sensing of Environment Remote Sensing of Environment 25:295-309

Huete A, Didan K, Miura T, Rodriguez EP, Gao X, Ferreira LG (2002) Overview of the radiometric and biophysical performance of the MODIS vegetation indices. Remote Sensing of Environment 83:195-213

Iqbal MF, Khan IA (2014) Spatiotemporal land use land cover change analysis and erosion risk mapping of Azad Jammu and Kashmir, Pakistan. The Egyptian journal of remote sensing and space science 17:209-229

Jordan CF (1969) Derivation of leaf-area index from quality of light on the forest floor. Ecology 50:663666

Kuhn M (2008) Building predictive models in R using the caret package. Journal of statistical software 28:1-26

Louhaichi M, Borman MM, Johnson DE (2001) Spatially located platform and aerial photography for documentation of grazing impacts on wheat. Geocarto International 16:65-70

Maltamo M, Bollandsås O, Gobakken T, Næsset E (2016) Large-scale prediction of aboveground biomass in heterogeneous mountain forests by means of airborne laser scanning. Canadian Journal of Forest Research 46:1138-1144 
Maltamo M, Packalen P (2014) Species-specific management inventory in Finland. In: Forestry applications of airborne laser scanning. Springer, pp 241-252

Mannan A et al. (2019) Application of land-use/land cover changes in monitoring and projecting forest biomass carbon loss in Pakistan. Global Ecology and Conservation 17:e00535

Næsset E (2004) Effects of different flying altitudes on biophysical stand properties estimated from canopy height and density measured with a small-footprint airborne scanning laser. Remote Sensing of Environment 91:243-255

Næsset E (2007) Airborne laser scanning as a method in operational forest inventory: Status of accuracy assessments accomplished in Scandinavia. Scandinavian Journal of Forest Research 22:433-442

Næsset E (2011) Estimating above-ground biomass in young forests with airborne laser scanning. International Journal of Remote Sensing 32:473-501

Næsset E (2014) Area-based inventory in Norway-from innovation to an operational reality. In: Forestry applications of airborne laser scanning. Springer, pp 215-240

Nuthammachot N, Askar A, Stratoulias D, Wicaksono P (2020) Combined use of Sentinel-1 and Sentinel-2 data for improving above-ground biomass estimation. Geocarto International:1-11

Nuthammachot N, Phairuang W, Wicaksono P, Sayektiningsih T (2018) Estimating aboveground biomass on private forest using Sentinel-2 imagery. Journal of Sensors 2018

Pandit S, Tsuyuki S, Dube T (2018) Estimating above-ground biomass in sub-tropical buffer zone community forests, Nepal, using Sentinel 2 data. Remote Sensing 10:601

Patenaude G, Milne R, Dawson TP (2005) Synthesis of remote sensing approaches for forest carbon estimation: reporting to the Kyoto Protocol. Environmental Science \& Policy 8:161-178

Pinty B, Verstraete M (1992) GEMI: a non-linear index to monitor global vegetation from satellites Vegetatio 101:15-20

Qamer FM, Shehzad K, Abbas S, Murthy M, Xi C, Gilani H, Bajracharya B (2016) Mapping deforestation and forest degradation patterns in western Himalaya, Pakistan. Remote Sensing 8:385

Qasim M, Hubacek K, Termansen M, Khan A (2011) Spatial and temporal dynamics of land use pattern in District Swat, Hindu Kush Himalayan region of Pakistan. Applied Geography 31:820-828

Raziq A, Xu A, Li Y, Zhao Q (2016) Monitoring of land use/land cover changes and urban sprawl in Peshawar City in Khyber Pakhtunkhwa: an application of geo-information techniques using of multitemporal satellite data. J Remote Sensing GIS 5:2 
Roujean J-L, Breon F-M (1995) Estimating PAR absorbed by vegetation from bidirectional reflectance measurements. Remote Sensing of Environment 51:375-384

Rousel J, Haas R, Schell J, Deering D Monitoring vegetation systems in the great plains with ERTS. In: Proceedings of the Third Earth Resources Technology Satellite-1 Symposium; NASA SP-351, 1973. pp 309-317

Saleemi MU (2015) Urban change detection of Lahore (Pakistan) using the Thematic Mapper Images of Landsat since 1992-2010

Shehzad K, Qamer FM, Murthy M, Abbas S, Bhatta LD (2014) Deforestation trends and spatial modelling of its drivers in the dry temperate forests of northern Pakistan-A case study of Chitral. Journal of Mountain Science 11:1192-1207

Sripada RP (2005) Determining in-season nitrogen requirements for corn using aerial color-infrared photography

Stephens P, Watt P, Loubser D, Haywood A, Kimberley M (2007) Estimation of carbon stocks in New Zealand planted forests using airborne scanning LiDAR. International Archives of Photogrammetry Remote Sensing and Spatial Information Sciences 36:389-394

Tucker CJ (1979) Red and photographic infrared linear combinations for monitoring vegetation. Remote Sensing of Environment 8:127-150

Uddin R, Ansari L, Ahmad A, Ullah S, Munir M, Sher K (2019) SOIL ANALYSIS, SPECIES COMPOSITION AND CARBON DYNAMICS OF ABIES PINDROW FOREST OF DIR KOHISTAN, PAKISTAN. APPLIED ECOLOGY AND ENVIRONMENTAL RESEARCH 17:8049-8058

Ullah S, Adler P, Dees M, Datta P, Weinacker H, Koch B (2017a) Comparing image-based point clouds and airborne laser scanning data for estimating forest heights. iForest-Biogeosciences and Forestry 10:273

Ullah S, Dees M, Datta P, Adler P, Koch B (2017b) Comparing airborne laser scanning, and image-based point clouds by semi-global matching and enhanced automatic terrain extraction to estimate forest timber volume. Forests 8:215

Ullah S, Dees M, Datta P, Adler P, Saeed T, Khan MS, Koch B (2020) Comparing the potential of stereo aerial photographs, stereo very high-resolution satellite images, and TanDEM-X for estimating forest height. International Journal of Remote Sensing 41:6976-6992

Ullah S, Dees M, Datta P, Adler P, Schardt M, Koch B (2019) Potential of modern photogrammetry versus airborne laser scanning for estimating forest variables in a mountain environment. Remote Sensing 11:661 
Ullah S, Farooq M, Shafique M, Siyab MA, Kareem F, Dees M (2016) Spatial assessment of forest cover and land-use changes in the Hindu-Kush mountain ranges of northern Pakistan. Journal of Mountain Science 13:1229-1237

Ullah S, Shafique M, Farooq M, Zeeshan M, Dees M (2017c) Evaluating the impact of classification algorithms and spatial resolution on the accuracy of land cover mapping in a mountain environment in Pakistan. Arabian Journal of Geosciences 10:67

Vafaei S, Soosani J, Adeli K, Fadaei H, Naghavi H, Pham TD, Tien Bui D (2018) Improving accuracy estimation of Forest Aboveground Biomass based on incorporation of ALOS-2 PALSAR-2 and Sentinel-2A imagery and machine learning: A case study of the Hyrcanian forest area (Iran). Remote Sensing 10:172

Walker W, Baccini A, Nepstad M, Horning N, Knight D, Braun E, Bausch A (2011) Field Guide for Forest Biomass and Carbon

\section{Estimation}

Zuur AF, leno EN, Elphick CS (2010) A protocol for data exploration to avoid common statistical problems.Methods in ecology and evolution 1:3-14

\section{Figures}

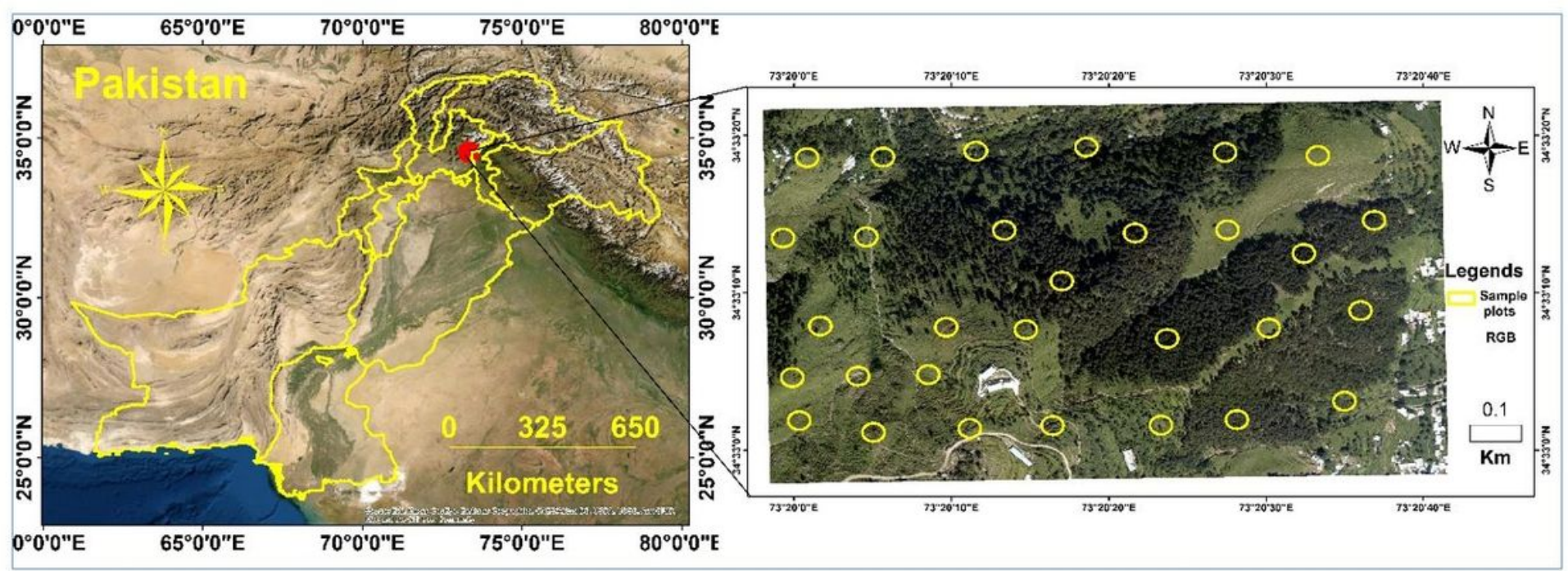

\section{Figure 1}

The geographical location of the study test site, the yellow circular depicts the location of ground inventory sample plots. Note: The designations employed and the presentation of the material on this map do not imply the expression of any opinion whatsoever on the part of Research Square concerning the legal status of any country, territory, city or area or of its authorities, or concerning the delimitation of its frontiers or boundaries. This map has been provided by the authors. 


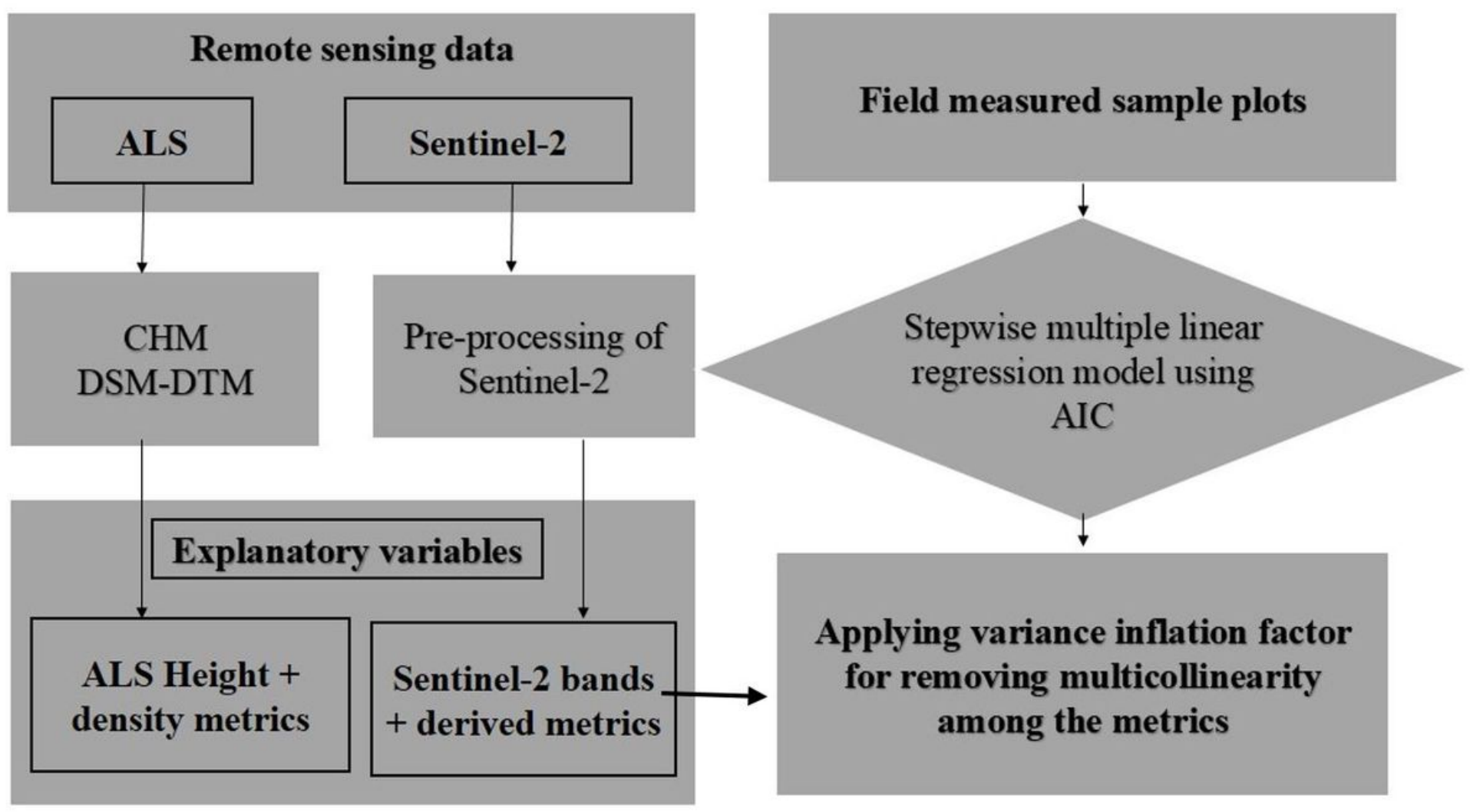

Figure 2

Flow chart of Research Methodology 

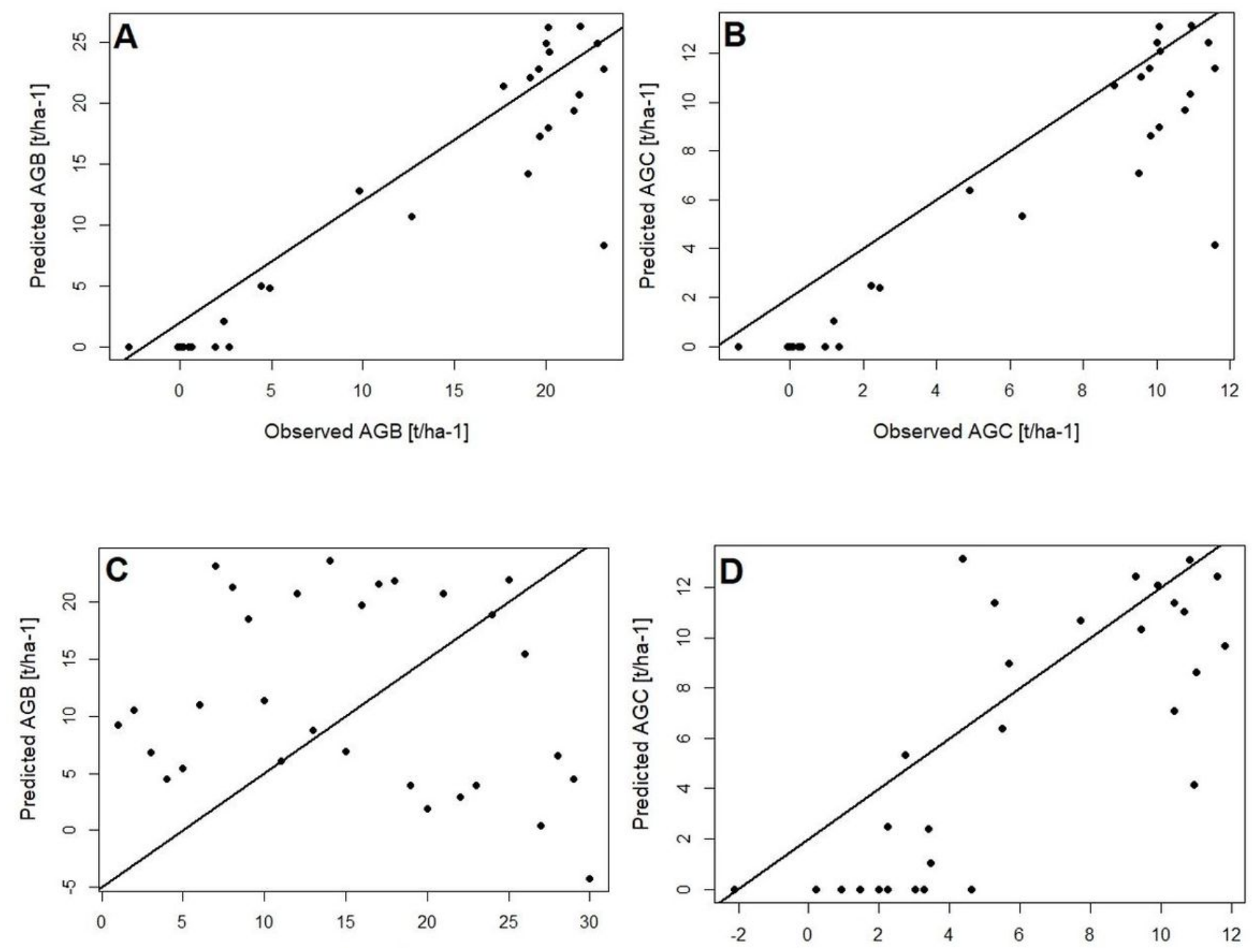

Figure 3

Final scatter plots depict Observed versus predicted biomass/carbon stock maps (Tons/ha-1) i.e., (A) ALS biomass (B) ALS Carbons Stock (C) Sentinel-2 Biomass, and (D) Sentinel-2 Carbon Stock 

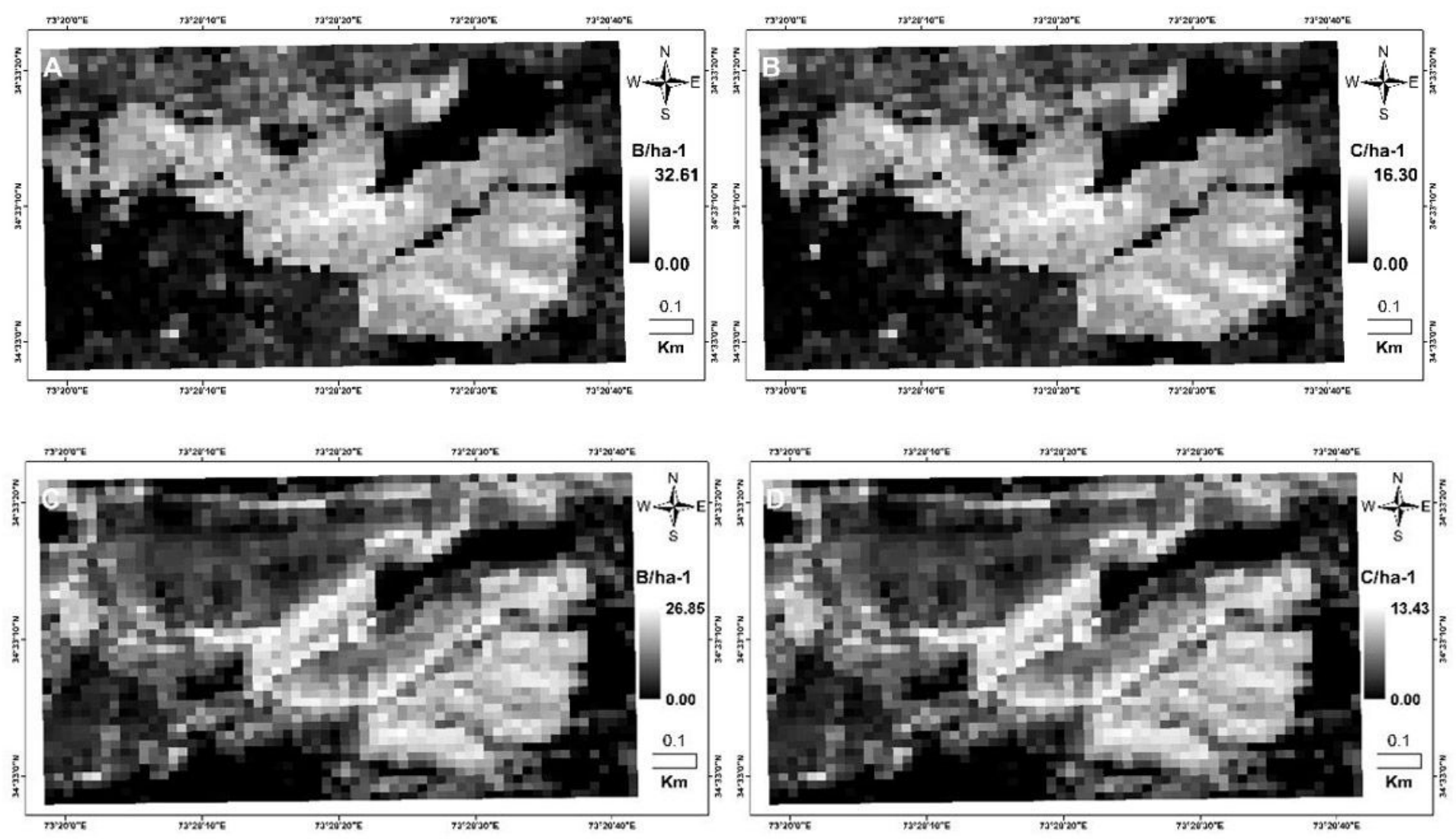

\section{Figure 4}

Final predicted biomass/carbon stock maps (Tons/ha-1) i.e., (A) ALS biomass (B) ALS Carbons Stock (C) Sentinel-2 Biomass, and (D) Sentinel-2 Carbon Stock. Note: The designations employed and the presentation of the material on this map do not imply the expression of any opinion whatsoever on the part of Research Square concerning the legal status of any country, territory, city or area or of its authorities, or concerning the delimitation of its frontiers or boundaries. This map has been provided by the authors.

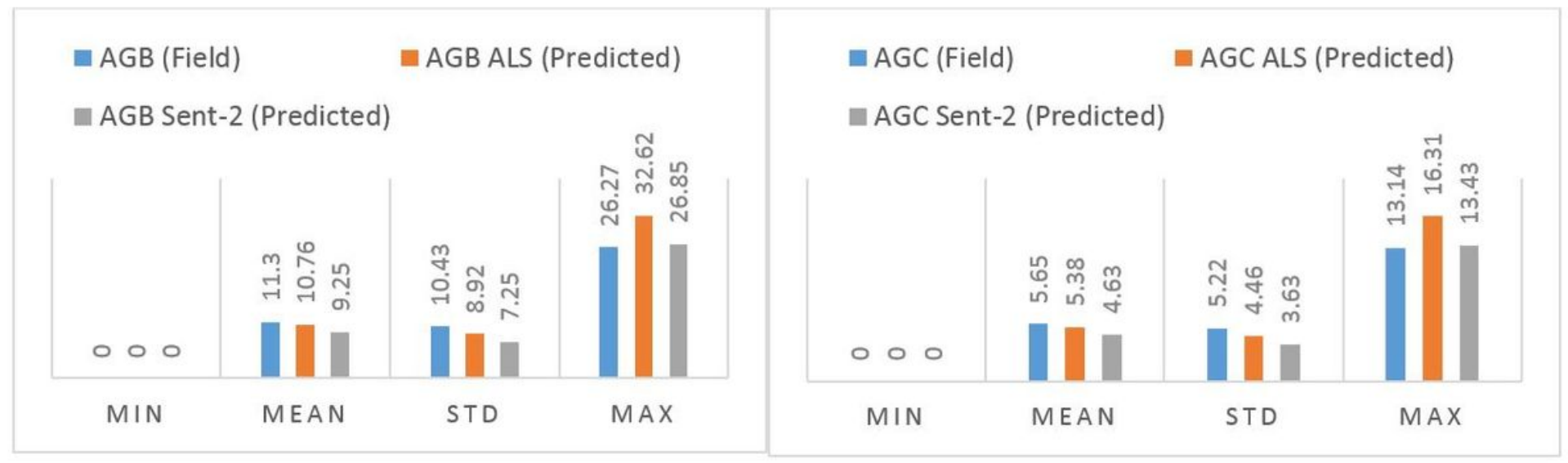

\section{Figure 5}

Comparison of ground versus predicted biomass/carbon stock (Ton/ha-1) 